\title{
Trilinguals' Identity Synergism Through Pragmatic Skills
}

\author{
Esmaeel Ali Salimi, Hadi Abedi
}

Allameh Tabataba'i University

\begin{abstract}
Correspondence concerning this article should be addressed to Hadi Abedi, Allameh Tabataba'i University Faculty of Persian Literature and Foreign Languages, Department of English Language and Literature, Corner of West Haqtalab St., South Allameh St., Pol-e Modiriyat, Tehran, Iran. E-mail: abedi.h@gmail.com
\end{abstract}

\begin{abstract}
Recent studies on bilingualism and pragmatics paid little attention to trilingual speakers. This investigation examined the trilinguals' identity synergism by drawing on their linguistic repertoire and discursive identity through pragmatic skills. For this purpose, twenty advanced EFL learners with Persian and Turkish as their mother tongues were homogenized through IELTS and played roles in Persian, Turkish, and English languages. For modeling, three monolingual native speakers of the English language responded to the English version of written discourse completion tests taken from the same role-plays. The data underwent content analysis to extract and codify the themes. The results revealed a synergy among the trilinguals' discursive systems when performing apology, complaint, refusal, and request speech acts. Multidirectional transfers among the trilinguals' Turkish, Persian, and English languages developed a form of English communication that was different from that of the native speakers' model. Gestures and mimes were the non-verbal strategies employed more in the trilinguals' Turkish and English languages than their Persian. This study helps researchers and teachers gain insight into identity, pragmatics, and multilingualism.
\end{abstract}

Keywords: synergic identity, trilingual learner, pragmatic skill, pragmatic transfer, speech act

\section{Introduction}

In recent decades, the cognitive aspects of language learning have been in the limelight of various ELT studies all over the world. Since learning arises in social, historical, and cultural interactions (Vygotsky, 1978), educational achievements fall under the influence of sociocultural issues (Block, 2007). Palovskaya and Lord (2018) maintained that the knowledge of the English language and the students' sociocultural backgrounds have essential influences on the students' language performances. In Kachru's view (2003) concerning the varieties of English used in diverse sociolinguistic contexts, English language speakers fall into three circles, i.e., the Inner Circle, the Outer Circle, and the Expanding Circle, with each one forming a local identity for its speakers all over the world (Lightbown \& Spada, 2006; Modiano, 2008; Ochs, 2008). In the Inner Circle or normproviding contexts such as the USA, the UK, Canada, Australia, and New Zealand, people adopt the English language as their mother tongue or first language. The Outer Circle or the norm-developing circle is the English of non-native and multilingual settings such as Malaysia, Singapore, India, Ghana, and Kenya, where English is the second language of the former colonies of the UK or the USA. The Expanding Circle or norm-dependent circle indicates countries like China, Japan, Greece, and Poland, where people learn English as a foreign language. The reflections of the world Englishes or the localized variants of English in the world have encouraged researchers to conduct some bilingual and multilingual studies. These inquiries have examined issues such as domain analysis, language choice, code-switching, and cross-cultural discourses (e.g., Hyrkstedt \& Kalaja, 2003; Thumboo, 2002). A multilingual person concurrently communicates with various languages, including English, in the local contexts. It is noteworthy that no one expects people from countries like India, Nigeria, and Singapore, who have experienced a colonial past, to achieve native-like proficiency in English (Sridhar, 1986).

Another important development in applied linguistics has been the concept of English as Lingua Franca (ELF). According to Kuo (2006), the Englishes of native speakers are not at the heart of research in international communication anymore, and researchers should consider the English of non-native speakers in their inquiries. This claim provides the background for conflicting attitudes toward ELF, i.e., a variety of English language used 
by non-native speakers, and a partial and instrumental knowledge to be taught in second language pedagogy (Kuo, 2006).

According to Lim and Hwang (2019), ELF has been an acceptable form of English communication. People with different first languages communicate with each other, and even the native speakers of English should learn ELF norms if they hope to communicate efficiently in an ELF community (Jenkins et al., 2011). According to Jenkins (2012), ELF users employ their bilingual or plurilingual resources to develop their cultural identity. They apply these resources to signify support for efficient communication rather than the correct usage of the standard English language. Jenkin's (2000, 2002) studies on ELF pronunciation revealed that ELF users speak more like their interlocutors to keep solidarity in their communication. In this way, ELF differs from English as a foreign language (EFL) since the EFL learners' target model is standard English, while ELF speakers strive to communicate efficiency. In other words, ELF users create multi-lingua-cultural identity over a national linguacultural identity (Baker, 2009). ELF for the advocators of world Englishes, or English varieties of post-colonial nations, is a monolithic or single global variety (Jenkins, 2012). Despite their judgments, ELF and world Englishes are both results of the spread of English beyond its native contexts in which the speakers create sociocultural identities, and do not follow the native speakers' norms (Seidlhofer \& Berns, 2009). However, while the varieties of English seem restricted in Kachru's (2003) World Englishes, ELF is closely involved in the globalization processes. (Jenkins et al., 2011). ELF is not the process of learning English to communicate like native speakers, but non-native speakers of English benefit from their multilingual resources, which English native speakers lack. Then, despite the native speakers of English who perceive EFL processes like codeswitching as a gap in English knowledge, ELF identifies these processes as a crucial multilingual pragmatic resource (Jenkins et al., 2011).

The above review implies that the mastery of knowledge domains is not enough for English learners, and they have to develop a related identity through the identity-transforming process (Palanac, 2019). This local identity affects the learners' way of thinking and using languages (Llurda, 2004) to such an extent that an interrelation develops between language and identity (Khatib \& Ghamari, 2011). Lingua-cultural identities also influence the ELF learners' accent preferences (Sung, 2016). The language learners shape new social networks in their language learning contexts (Riley, 2006; Ushioda, 2009), and their discourses, as well as their identities, are manifestations of this cultural membership (Brown et al., 2005). Thus, the focal purpose of the present inquiry is to examine the linguistic systems of Iranian trilinguals who adopt the institutionalized varieties of English in the Expanding Circle (Kachru, 1986), which differ from those of British or American standard English. If acquiring a language means a new identity construction (Llurda, 2004; Seidlhofer, 1999), then the bilinguals may hold two or more identities coincidently (Kondo, 2008), and they do not merely duplicate the native speakers' language norms (Kasper, 1997). In learning English as an international language, the learners' pedagogical models and identities are valued. Here, the learners don't need to be familiar with native speakers' norms to communicate in the world Englishes (Ishihara \& Cohen, 2004). Given this premise, the bilinguals' linguistic features, and identities may be different from that of native speakers of English, and this has been the main impetus for conducting the present study.

\section{Literature Review}

Several impressive studies on communicative competence (e.g., Ellis, 2008) have led researchers to its constitutive elements. These elements are grammatical, discoursal, strategic, and pragmatic competences (Canale, 1983, as cited in Takkaç Tulgar, 2016), among which pragmatic competence, was chosen as the focus of the present study. Pragmatic competence deals with an individual's linguistic choices, linguistic limitations, and linguistic impacts in communication (Crystal, 1997). In Crystal's (1985, as cited in Takkaç Tulgar, 2016) view, pragmatics involve the study of the language users' preferences, interactional contexts, and the impacts of their speech on the other participants. According to Tajeddin et al. (2015), linguistic appropriateness is different from pragmatic appropriateness. Linguistic appropriateness refers to linguistic performance or the actual manifestation of grammatical utterances. Pragmatic appropriateness, on the other hand, is the members' awareness of the social and cultural norms of a community (Rose \& Kasper, 2001), including its identities (Llurda, 2004; Seidlhofer, 1999). Thus, learning a language is not merely understanding the grammar and the vocabulary of that language, but the appropriate use of the learned components for communication (Bayat, 2013). Consequently, when people from two different cultures communicate, their cultural backgrounds, which 
are deeply grounded in their contexts, influence their interactions (Al-Issa, 2003). These interactions develop between the discourse and the context of use (Paltridge, 2012), and constructs the pragmatic competence. Pragmatic competence is a context-dependent concept (Kondo, 1997) that contains speech or communicative acts (Al-Ghanati \& Roever, 2010; Austin, 1962; Cohen \& Shively, 2007; Searle, 1975). Cohen (1997, as cited in Allami \& Naeimi, 2010) reported that EFL learners cannot reach the highest levels of pragmatic competence because of their limited EFL contexts. However, the inquiries on ELF pragmatics have reached different results, as ELF focuses on efficient communication and not the EFL learners' target model of standard English. According to Jenkins et al. (2011), the research on ELF pragmatics has mainly centered on ELF speakers' cooperation in conversations, ELF strategies like repetition for signaling non-understanding in communication, in-group identity construction against intelligibility or shared resources like idiomatic expression, and utilizing discourse markers like chunking. It is worthy to note that earlier studies on pragmatic competence mostly took the linguistic aspects of monolingual or bilingual learners into account, and less was attention paid to trilingual learners' pragmatic skills or speech acts.

Earlier bilingual and multilingual studies mostly examined code-switching, which refers to the use of codemixing between the languages of a bilingual or multilingual in intra-sentential or inter-sentential forms (Chan, 2018). People employ code-switching to perform their pragmatic functions since it helps them to convey their meanings better and make their communication work (Cogo, 2007, as cited in Chan, 2018). Code-switching indicates the bilingual or multilingual member's culture and identity in a community of practice (Klimpfinger, 2007). In a study conducted in Hong Kong, Wang and Kirkpatrick (2015) investigated the implementation of the trilingual policy. They noticed that the trilingual policy and its educational effectiveness varied significantly across schools. Chan $(2018,2019)$ observed that trilinguals held Hong Kong identity and applied code-switching among Cantonese, English, and Putonghua, with the dominant use of the forms Cantonese-English or EnglishPutonghua. According to his findings, using Pure-Cantonese, Pure-English, or Pure-Putonghua made communication difficult in Hong Kong. In the same direction, Gonzales' (2016) study on trilinguals in the Philippines revealed that intra-sentential code-switching occurred more than inter-sentential code-switching, and trilinguals mostly tried word-level switches when there was no chance of morphological code-switching. In another study on the translanguaging framework, Choi (2019) observed unique and complicated trilingual practices, such as translation and code-switching. They employ these communicative strategies to satisfy the communicative needs of their interlocutors.

It is noteworthy that recent studies conducted on bilingualism and multilingualism did examine some pragmatic aspects like the transfer of pragmatic skills. Studies like Döpke (2000), Hulk and Müller (2000), and Müller and Hulk (2001) suggested various interplays between the two developing languages of bilinguals. These interactions appear in positive or negative pragmatic transfers. Negative transfers indicate the use of L1 pragmatic knowledge, which seems to vary from those of target language norms, and positive transfers denote L1 pragmatic knowledge practice, which is compatible with L2 norms. These transfers pass mostly from the pragmatic and cultural competence of the bilinguals' first languages to their target language (Kasper, 1992).

Bilinguals manifest these pragmatic transfer processes in their speech acts. The speech acts in pragmatics are request, refusal, complaint, apology, regret, forgiveness, responsibility, and offering redress. Request (Brown \& Levinson, 1987), as a face-threatening act, makes the hearer do something directly or indirectly, and it is available to speakers in all languages of the world (Blum-Kulka \& Olshtain, 1984). Saying no directly or indirectly to a request, invitation, and suggestion or offer signifies the refusal speech act. According to Cohen (1996), an indirect refusal requires a high level of pragmatic competence, and different strategies are requires across languages and cultures to avoid giving offence (Al-Eryani, 2007; Siebold \& Busch, 2015).

Another aspect of the speech act is the complaint, which is an expression of annoyance or disappointment about some wrongdoing (Monzoni, 2009). It occurs when the speaker tries to persuade the hearer to do something to repair the damage (Searle, 1975), and Vásquez (2011) has divided it into direct and indirect forms. Apology as a universal act of face-saving and politeness (Cohen \& Olshtain, 1983) has been explored in different languages by Bataineh and Bataineh (2008) and Chamani and Zareipur (2010). Fraser (1981) organized the apology speech acts into nine categories, i.e., apology announcement, obligation to apologize, offering an apology, requesting acceptance of apology, regret for the offense, requesting forgiveness, acknowledging responsibility for the offending act, promising forbearance from a similar offending act, and offering redress. 
Pragmatic competence includes various skills and speech acts (Backus \& Yağmur, 2017), which refer to the social aspect of discourse or sociopragmatics. This social aspect of discourse is the origin of a member's identity in the speech community (Brown et al., 2005). This identity is multiple, shifting, in conflict, and related to social, cultural, and political contexts. In other words, identity is created, maintained, and negotiated through discourse (Varghese et al., 2005). Since bilinguals benefit from two discursive systems (Kasper, 1992), they are capable of combining several identities (Davies \& Harré, 1990), which can have a strong influence on learner achievement (Aliakbari \& Amiri, 2018). These identities show a continuum of in-group to out-group memberships (Duszak, 2002), which all are different and take place in conversational contexts (Davies \& Harré, 1990). The question is whether the bilinguals deploy their discursive systems separately, or they create an interaction between the two systems in their communication. To reply to this question, conducting the present study appeared to be urgent.

The present study focuses on pragmatic skills and identity (Brown et al., 2005) in Iran, which is located in Kachru's (2003) Expanding Circle. The reviewed studies concerning pragmatics mainly dealt with pragmatic appropriateness (Tajeddin et al., 2015), pragmatics and identity (Llurda, 2004; Seidlhofer, 1999), EFL/ELF contexts and pragmatics (Kondo, 1997; Allami \& Naeimi, 2010), speech acts (Al-Ghanati \& Roever, 2010), and pragmatic transfers (Döpke, 2000). These studies examined monolingual or bilingual learners, and some reflected trilinguals' code-switching (Chan, 2018) and translanguaging (Choi, 2019) in various contexts. The synergy among trilinguals' pragmatic skills seems to be a gap in the previous studies; therefore, to bridge this gap, the current inquiry examined the trilinguals with Persian and Turkish as their first language and English as a foreign language. This study is an attempt to explore synergy among the identities created for each of these three discursive systems by performing some pragmatic skills. The pragmatic skills, including request, refusal, complaint, apology, regret, forgiveness, responsibility, and offering redress, all at once, were given less attention in earlier studies, particularly when the synergy of trilinguals' pragmatic skills was concerned. Those few studies on identity synergism merely viewed synergy in the personal or social identities of two different individuals (Heger \& Gaertner, 2018), or the couple's identity synergy, i.e., fusion (Walsh \& Neff, 2018). Another interesting issue of the present study is the gestures and mimes applied by the trilinguals throughout their role-plays. Gestures and mimes as other aspects of pragmatics were rarely noted in previous studies.

\section{The purpose of the study}

Knowing another language means having a new identity (Llurda, 2004; Seidlhofer, 1999). Discourse shapes identity and has a social aspect called pragmatics (Brown et al., 2005), which consists of a variety of skills (Backus \& Yağmur, 2017).

The present study assumed that trilingual participants might create different discursive identities through their pragmatic skills. It aimed to investigate the trilinguals' identity synergism through performing some roleplays in Persian and Turkish as their native languages and English as their target language. Thus, this study tried to answer the following questions:

1. How do the trilinguals deploy discursive identities through pragmatic skills (speech acts) in various contexts?

2. Which discursive identity is more prevalent for the trilinguals to construct identity synergism: English, Persian, or Turkish?

\section{Methodology}

\section{Participants}

The participants of this study were twenty advanced EFL learners who acquired Persian and Turkish as their first languages in childhood and were selected via convenience sampling. According to Dörnyei (2007), the researchers should try convenience sampling when participants possess certain key features that are related to the purpose of the investigation. An IELTS test was administered before the data collection to delineate the participants' levels of English proficiency. The advanced level of proficiency was the accepted level for the present study. 
The participants of this study were twenty trilinguals (Table 1) who acquired Persian and Turkish as native languages and English as a target language. The participants learned the English language to the advanced level in English language institutes and were both females and males selected conveniently. The key requirement in selecting the participants was their ability to use the three languages, i.e., Persian, Turkish, and English. The participants acquired Persian and Turkish concurrently as their native languages.

Table 1

Trilingual Participants

\begin{tabular}{llcccc}
\hline & & Frequency & Percent & Valid Percent & Cumulative Percent \\
\hline Valid & Male & 7 & 35.0 & 35.0 & 35.0 \\
& Female & 13 & 65.0 & 65.0 & 100.0 \\
& Total & 20 & 100.0 & 100.0 & \\
\hline
\end{tabular}

\section{Materials}

For collecting the data, the current study has applied the Written Discourse Completion Tests (WDCTs) and role-plays taken from Liu's study (2006). The participants took the Persian, Turkish, and English versions of WDCTs. All versions were equivalent in terms of formats and contents. For modeling purposes, three monolingual English native speakers also received the English version of WDCTs. The researchers benefited from the native speakers' models since they compared the participants' English language productions with those of native speakers.

\section{Data Collection Procedure}

The data collection of the present study was conducted in two phases. In phase one, three native speakers of the English language from California, United States of America, received the English version of the WDCT for modeling purposes. The trilingual participants received English, Turkish, and Persian versions of WDCTs through social media such as telegram. In a WDCT, the participants had to give their responses to situations designed to elicit certain pragmatic functions.

In phase two, the participants had to perform the English, Turkish, and Persian versions of WDCTs separately through role-plays. A counter-balancing technique was used to avoid the introduction of confounding variables in creating those situations. For this reason, the participants received the role-plays separately based on their language formats, i.e., English, Turkish, and Persian, over three weeks. The participants performed the roleplays. The researchers videotaped the role-plays after obtaining permission from the participants as an ethical issue.

\section{Data Analysis}

By applying content analysis as one of several qualitative methods, the study analyzed the data, and the meaning of the data was interpreted (Schreier, 2012). Therefore, content analysis reduced the data to concepts that described the research phenomenon (Elo \& Kyngäs, 2008). In other words, a coding scheme was developed to extract and codify the dialogs of the participants in the role-plays and WDCTs.

\section{Results}

The present study has collected its data via WDCTs and role-plays designed by Liu (2006). In the first phase, the participants created some situations through WDCTs in the forms of some speech acts such as apologizing, refusing, complaining, accepting, and requesting in three languages, i.e., Persian, Turkish, and English. In the second phase, the participants performed those generated situations through role-plays.

Samples of naturally occurring speech acts were encoded using modified version strategies outlined by Fraser (1981), Olshtain (1989), Cohen (1996), Blum-Kulka and Olshtain (1984), and Vásquez (2011). The researchers assigned a code to each strategy from A1 to D. Table 2 presents the apology strategies and their codes: 
ESMAEEL ALI SALIMI, HADI ABEDI

Table 2

Illocutionary force indicating strategies and their codes

\begin{tabular}{lll}
\hline Code & \multicolumn{1}{c}{ Strategy } & \multicolumn{1}{c}{ Examples } \\
\hline A. & Expressing regret & Illocutionary Force Indicating Apology \\
& & Persian: Kheili kheili ozr mikham \\
& & Turkish: Chokh ozr istiram \\
A2 $\quad$ Requesting apology acceptance & English: I'm very sorry for \\
& & Persian: Mazarat mikham fekr nemikardam biofte \\
& & Turkish: Otubus sorati chokedi sak dushdo, chok chok bagheshla \\
& & English: Let me apologize as my suitcase was heavy and I could not put it there \\
A3 & Acknowledging responsibility for an offending act & Persian: Aslan havasam nabud \\
& & Turkish: Deghat elamadem \\
& A4 & English: I did not wish it to happen. \\
& & Persian: Khesaratesho jobraan mikonam \\
& & Turkish: Najur jobran eliem \\
& English: I will pay for that. \\
\hline
\end{tabular}

B.

B2 Annoyance strategy

B3 Direct accusation strategy

B4 Indirect accusation strategy
B1 Hint

\section{Illocutionary Force Indicating Complaint}

Persian: Ghasde mozahemat nadashtam

Turkish: Nakhabar goimishiz ghonshi.

English: Sorry for bothering you.

Persian: Man farad emtehan daram.

Turkish: Man estirem darsemi yetishiim.

English: I need to study for the exam.

Persian:Bacheha kheili shologh mikonan.

Turkish: Lotf eleyosuz oshakhlarin saket eliosuz.

English: Your kids are very noisy.

Persian: Lotfan ye emshab molahezeye man ro bokonid.

Turkish: Bir ghad raayat eliin.

English: There is so much noise. Could you please ask the kids to play quietly?

\begin{tabular}{|c|c|c|}
\hline C. & \multicolumn{2}{|c|}{ Illocutionary Force Indicating Refusal } \\
\hline \multirow[t]{3}{*}{$\mathrm{C} 1$} & Direct refusal & Persian: Man emruz kar daram nemitunam bishtar az saate edari bemunam. \\
\hline & & Turkish: Ishim var galamirim vala. \\
\hline & & English: I have a problem. I should go. \\
\hline \multirow[t]{3}{*}{$\mathrm{C} 2$} & Indirect refusal & $\begin{array}{l}\text { Persian: Aghaye rais man vaghean ahamiate in projaro dark mikonam ama } \\
\text { tavalode madarame. }\end{array}$ \\
\hline & & Turkish: Mazerat estirim manim moshkelem var, ejaze versus man tez gedem. \\
\hline & & English: Sorry sir, but I have my own plan after work. \\
\hline D. & \multicolumn{2}{|c|}{ Illocutionary Force Indicating Acceptance of a Request } \\
\hline \multirow[t]{3}{*}{ D1 } & Direct request & Persian: Yekam pul dari be man bedi? \\
\hline & & Turkish: varin mana pul verain? \\
\hline & & English: Is it possible to give me money? \\
\hline \multirow[t]{3}{*}{ D2 } & Indirect request & Persian: Dooste aziz baraye bargasht be khane be kami pul niaaz daram, \\
\hline & & Turkish: Manim pulem tukanib, eva gemmaghish pulum yok \\
\hline & & English: I left my wallet at home. \\
\hline \multirow[t]{3}{*}{ D3 } & Direct acceptance of a request & Persian: Iraadi nadare har kodumo mikhain entekhab konid. \\
\hline & & Turkish: Iraad yok, har nama san istiasan entekhab ela. \\
\hline & & English: It doesn't matter; you can change with what else you want. \\
\hline \multirow[t]{3}{*}{ D4 } & Indirect acceptance of a request & Persian: Moshkeli nist jenab maghaze motaalegh be khodetune. \\
\hline & & Turkish: Uz maghazaizde. Har biren estiriiz ghabel yohkde. \\
\hline & & English: As you wish. \\
\hline
\end{tabular}
ing Refus

Persian: Man emruz kar daram nemitunam bishtar az saate edari bemunam.

Turkish: Ishim var galamirim vala. tavalode madarame.

Turkish: Mazerat estirim manim moshkelem var, ejaze versus man tez gedem.

English: Sorry sir, but I have my own plan after work.

English: As you wish. 
The first situation offered apology speech acts. Some participants started their speeches with regret for the offense and applied intensifiers to make it more polite in all three languages. Some others opened their communications by asking the hearer to accept an apology. Acknowledging responsibility for the offending act was what all the participants did next. Offering redress was what the participants expressed at the end of their conversations. (Table2).

The native speakers of the English language did not open their conversations with apology acceptance, but they regretted the offense again. After asking the hearer to accept an apology, the trilingual participants expressed their regret for the offense. The English native speakers also started their conversations with regret for the offense. The purpose of using intensifiers in this part of the communication was to minimize the facethreatening acts. They also raised politeness issues. Acknowledging responsibility for the offending act was what all the participants did next. They all offered redress at the end of their conversations.

The results of the above analyses revealed that the trilingual participants were almost equal in the use of various strategies for apology speech acts (Table 3). The tables note the trilinguals' higher application of requesting apology acceptance (Persian $21.5 \%$, Turkish 20.5\%, English 20.8\%) and acknowledging responsibility (Persian 26.6\%, Turkish 26\%, English 26\%) than the native speakers of English as presented in Table 4 (16.7\%). In expressing regret and offering redress, native speakers of English demonstrated a higher percent (33\%) in comparison to the trilinguals.

Table 3

Trilinguals' illocutionary force indicating apology

\begin{tabular}{|c|c|c|c|c|c|}
\hline Code & Strategy & Frequency & Percent & Valid Percent & Cumulative Percent \\
\hline \multicolumn{6}{|c|}{ Apology in Persian } \\
\hline A1 & Expressing regret & 22 & 27.8 & 27.8 & 27.8 \\
\hline A2 & Requesting apology acceptance & 17 & 21.5 & 21.5 & 49.4 \\
\hline A3 & Acknowledging responsibility & 21 & 26.6 & 26.6 & 75.9 \\
\hline \multirow[t]{2}{*}{ A4 } & Offering redress & 19 & 24.1 & 24.1 & 100.0 \\
\hline & Total & 79 & 100.0 & 100.0 & \\
\hline \multicolumn{6}{|c|}{ Apology in Turkish } \\
\hline A1 & Expressing regret & 19 & 24.1 & 26.0 & 26.0 \\
\hline A2 & Requesting apology acceptance & 15 & 19.0 & 20.5 & 46.6 \\
\hline A3 & Acknowledging responsibility & 19 & 24.1 & 26.0 & 72.6 \\
\hline \multirow[t]{2}{*}{ A4 } & Offering redress & 20 & 25.3 & 27.4 & 100.0 \\
\hline & Total & 73 & 92.4 & 100.0 & \\
\hline \multicolumn{6}{|c|}{ Apology in English } \\
\hline A1 & Expressing regret & 20 & 25.3 & 26.0 & 26.0 \\
\hline A2 & Requesting apology acceptance & 16 & 20.3 & 20.8 & 46.8 \\
\hline A3 & Acknowledging responsibility & 20 & 25.3 & 26.0 & 72.7 \\
\hline \multirow[t]{2}{*}{ A4 } & Offering redress & 21 & 26.6 & 27.3 & 100.0 \\
\hline & Total & 77 & 97.5 & 100.0 & \\
\hline
\end{tabular}

Table 4

Illocutionary force indicating apology for native speakers of English

\begin{tabular}{llcccc}
\hline Code & \multicolumn{1}{c}{ Strategy } & Frequency & Percent & Valid Percent & Cumulative Percent \\
\hline A1 & Expressing regret & 6 & 6.0 & 33.3 & 33.3 \\
A2 & Requesting apology acceptance & 3 & 3.0 & 16.7 & 50.0 \\
A3 & Acknowledging responsibility & 3 & 3.0 & 16.7 & 66.7 \\
A4 & Offering redress & 6 & 6.0 & 33.3 & 100.0 \\
& Total & 18 & 18.0 & 100.0 & \\
\hline
\end{tabular}


The other situation asked the participants to form a complaint, and the participants began it with a hint (Table 2). The accusation strategies employed by the trilingual participants were uttered both directly and indirectly in these three languages. They displayed an interaction among the trilinguals' language competencies. In this type of strategy, English native speakers were more indirect and polite. The last complaint strategy applied by the participants was the annoyance strategy. This strategy revealed no variances from what the native speakers of English reported (Table 2).

Tables 5 shows that the trilingual participants equally followed the complaints strategies, i.e., hint (25\%), accusation (25\%), and annoyance (25\%) in Persian, Turkish, and English, while the native speakers of English language handled $16.7 \%$ hint, $16.7 \%$ annoyance, $56.7 \%$ indirect complaint strategies, and $10 \%$ direct complaint ones (Table 6). The trilingual participants created both direct and indirect complaints, although the direct complains (15\%) were observed more than indirect ones (10\%). The English native speakers were more indirect (56.7\%) in making the complaint.

Table 5

Trilinguals' illocutionary force indicating complaint

\begin{tabular}{|c|c|c|c|c|c|}
\hline Code & Strategy & Frequency & Percent & Valid Percent & Cumulative Percen \\
\hline \multicolumn{6}{|c|}{ Complaint in Persian } \\
\hline B1 & Hint & 20 & 24.1 & 25.0 & 25.0 \\
\hline B2 & Annoyance strategy & 20 & 24.1 & 25.0 & 75.0 \\
\hline B3 & Direct accusation strategy & 24 & 29 & 30.0 & 90.0 \\
\hline \multirow[t]{2}{*}{ B4 } & Indirect complaint & 16 & 19.2 & 20.0 & 100.0 \\
\hline & Total & 80 & 96.4 & 100.0 & \\
\hline \multicolumn{6}{|c|}{ Complaint in Turkish } \\
\hline B1 & Hint & 20 & 24.1 & 25.0 & 25.0 \\
\hline B2 & Annoyance strategy & 20 & 24.1 & 25.0 & 75.0 \\
\hline B3 & Direct accusation strategy & 24 & 29 & 30.0 & 90.0 \\
\hline \multirow[t]{2}{*}{ B4 } & Indirect complaint & 16 & 19.2 & 20.0 & 100.0 \\
\hline & Total & 80 & 96.4 & 100.0 & \\
\hline \multicolumn{6}{|c|}{ Complaint in English } \\
\hline B1 & Hint & 20 & 24.1 & 25.0 & 25.0 \\
\hline B2 & Annoyance strategy & 20 & 24.1 & 25.0 & 75.0 \\
\hline B3 & Direct accusation strategy & 24 & 29 & 30.0 & 90.0 \\
\hline \multirow[t]{2}{*}{ B4 } & Indirect complaint & 16 & 19.2 & 20.0 & 100.0 \\
\hline & Total & 80 & 96.4 & 100.0 & \\
\hline
\end{tabular}

Table 6

Illocutionary force indicating complaint for native speakers of English

\begin{tabular}{llcccc}
\hline Code & \multicolumn{1}{c}{ Strategy } & Frequency & Percent & Valid Percent & Cumulative Percent \\
\hline B1 & Hint & 3 & 3.0 & 16.7 & 16.7 \\
B2 & Annoyance strategy & 3 & 3.0 & 16.7 & 33.4 \\
B3 & Direct complaint & 2 & 2.0 & 10 & 43.4. \\
B4 & Indirect complaint & 10 & 10.0 & 56.7 & 100.0 \\
& Total & 18 & 18.0 & 100.0 & \\
\hline
\end{tabular}

Refusal strategies were indirectly reached by the participants, although there were some that were stated directly and could be mostly detected in the Turkish language (Table 2). In these strategies, the pragmatic transfers from pragmalinguistic to sociopragmatic knowledge were apparent among the trilinguals' linguistic systems. The participants employed more first language norms than target language in their English communication due to the cultural differences and the context of use. The trilingual participants gave excuses for leaving the window open and mitigated the face-threatening acts by applying remedy utterances at the end of their talks. Some others modified their context by asking the hearer to close the window. 
Table 7 shows that the trilinguals indirectly employed the refusals in Persian (65\%), while direct refusals (75\%) occurred more than indirect ones (25\%) in Turkish. It also indicates that the trilinguals equally applied both direct (50\%) and indirect (50\%) refusal strategies when communicating in English. However, the native speakers of the English language applied the indirect strategy in their refusal speech acts (Table 8).

Table 7

Trilinguals' illocutionary force indicating refusal

\begin{tabular}{|c|c|c|c|c|c|}
\hline Code & Strategy & Frequency & Percent & Valid Percent & Cumulative Percent \\
\hline \multicolumn{6}{|c|}{ Refusal in Persian } \\
\hline $\mathrm{C} 1$ & Direct refusal & 7 & 7.0 & 35.0 & 35.0 \\
\hline \multirow[t]{2}{*}{$\mathrm{C} 2$} & Indirect refusal & 13 & 13.0 & 65.0 & 100.0 \\
\hline & Total & 20 & 20.0 & 100.0 & \\
\hline \multicolumn{6}{|c|}{ Refusal in Turkish } \\
\hline $\mathrm{C} 1$ & Direct refusal & 12 & 12.0 & 75.0 & 75.0 \\
\hline \multirow[t]{2}{*}{$\mathrm{C} 2$} & Indirect refusal & 6 & 6.0 & 25.0 & 100.0 \\
\hline & Total & 20 & 20.0 & 100.0 & \\
\hline \multicolumn{6}{|c|}{ Refusal in English } \\
\hline $\mathrm{C} 1$ & Direct refusal & 12 & 12.0 & 75.0 & 75.0 \\
\hline \multirow[t]{2}{*}{$\mathrm{C} 2$} & Indirect refusal & 6 & 6.0 & 25.0 & 100.0 \\
\hline & Total & 20 & 20.0 & 100.0 & \\
\hline
\end{tabular}

\section{Table 8}

Illocutionary force indicating refusal for native speakers of English

\begin{tabular}{llcccc}
\hline Code & \multicolumn{1}{c}{ Strategy } & Frequency & Percent & Valid Percent & Cumulative Percent \\
\hline C2 & Indirect refusal & 3 & 3.0 & 100.0 & 100.0 \\
& Total & 100.0 & 100.0 & & \\
\hline
\end{tabular}

In the last situation, i.e., acceptance of a request, some participants applied lengthy speeches, and the cultural differences made the participants implement more native languages' norms in English communication.

The trilingual participants employed both direct (35\%) and indirect (15\%) requests in Persian, Turkish, and English (Table 9). In accepting the requests, trilingual participants performed more indirectly in Persian (42.5\%) and Turkish (37.5\%), but they applied both direct (20\%) and indirect (30\%) acceptance in English communication, although the direct examples were more common. The native speakers of the English language (Table 10) made use of indirect requests (50\%), but they accepted the request directly (50\%).

\section{Discussion}

The current study has strived to examine the trilinguals' discursive identities through performing pragmatic skills such as apology, complaint, refusal, and request. Since identity and language behaviors are interrelated (Heger \& Gaertner, 2018) by learning English as an international language, the learners construct an identity that influences their way of thinking and language uses (Llurda, 2004). Many studies have focused on identity construction. Ochs (2008) believed that individuals negotiate their identities through language, while Lightbown and Spada (2006) proposed that people shape a new identity by learning a new language. Khatib and Ghamari (2011) also found an intertwinement between language and identity. The study conducted by Heger and Gaertner (2018) on identity and language behaviors led the researchers of the present study to focus on the trilinguals' speech acts and examine the actual interactions among the trilinguals' language identities.

Since the present study falls into the third or Expanding Circle of Kachru (2003), the researchers expected the participants to depend more on native speakers' norms. Despite that, the findings displayed a synergy among 
Table 9

Trilinguals' illocutionary force indicating requests

\begin{tabular}{|c|c|c|c|c|c|}
\hline Code & Strategy & Frequency & Percent & Valid Percent & Cumulative Percent \\
\hline \multicolumn{6}{|c|}{ Request in Persian } \\
\hline D1 & Direct request & 14 & 14.0 & 35.0 & 35.0 \\
\hline D2 & Indirect request & 6 & 6.0 & 15.0 & 50.0 \\
\hline D3 & Direct acceptance & 3 & 3.0 & 7.5 & 57.5 \\
\hline \multirow[t]{2}{*}{ D4 } & Indirect acceptance & 17 & 17.0 & 42.5 & 100.0 \\
\hline & Total & 40 & 40.0 & 100.0 & \\
\hline \multicolumn{6}{|c|}{ Request in Turkish } \\
\hline D1 & Direct request & 14 & 14.0 & 35.0 & 35.0 \\
\hline D2 & Indirect request & 6 & 6.0 & 15.0 & 50.0 \\
\hline D3 & Direct acceptance & 5 & 5.0 & 12.5 & 62.5 \\
\hline \multirow[t]{2}{*}{ D4 } & Indirect acceptance & 16 & 16.0 & 37.5 .0 & 100.0 \\
\hline & Total & 40 & 40.0 & 100.0 & \\
\hline \multicolumn{6}{|c|}{ Request in English } \\
\hline D1 & Direct request & 14 & 14.0 & 35.0 & 35.0 \\
\hline D2 & Indirect request & 6 & 6.0 & 15.0 & 50.0 \\
\hline D3 & Direct acceptance & 8 & 8.0 & 20.0 & 70.0 \\
\hline \multirow[t]{2}{*}{ D4 } & Indirect acceptance & 12 & 12.0 & 30.0 & 100.0 \\
\hline & Total & 40 & 40.0 & 100.0 & \\
\hline
\end{tabular}

Table 10

Illocutionary force indicating requests for native speakers of English

\begin{tabular}{llcccc}
\hline Code & \multicolumn{1}{c}{ Strategy } & Frequency & Percent & Valid Percent & Cumulative Percent \\
\cline { 2 - 6 } D2 & Indirect request & 3 & 3.0 & 50.0 & 50.0 \\
D3 & Direct acceptance & 3 & 3.0 & 50.0 & 100.0 \\
& Total & 6 & 6.0 & 100.0 & \\
\hline
\end{tabular}

the trilinguals' linguistic systems when they lacked the appropriate target norms in English language communication. In other words, the trilinguals employ the first language norms when they lack enough pragmatic knowledge in English language communication. In this way, the present study validates Jenkins' (2011, 2012) claims concerning ELF users' ability to access their bilingual or plurilingual resources to support efficient communication rather than the correct usage of the standard English language. The trilinguals' identity synergism falls in line with the fusion theory of Heger and Gaertner (2018), who examined identity synergism. Their claim regarding identity synergism implies a reciprocal group-serving among the members of a community. Of course, according to the present study, this identity synergism or reciprocal activations of identities occurs inside the trilinguals' linguistic systems in performing the speech acts in Persian, Turkish, and English languages. The findings revealed that the trilinguals employ their first languages to prevent any breaks in performing their speech acts. They also supported the study conducted by Walsh and Neff (2018) concerning the degree of identity fusion. Identity fusion indicates that a higher degree of identity synergism encourages individuals to communicate with fewer threats and conflicts. The participants of the current study sought to communicate their meanings synergically by practicing the verbal and non-verbal linguistic assets of their native and target languages. Therefore, it confirmed Goertzel's report (2009) about the construction of a mechanism called cognitive synergy, since the trilinguals tried to apply their trilingual cognitive knowledge synergically. This cognitive synergy was performed more effectively in combination with non-interactional and isolated performance, such as communicating in the target language, i.e., English.

The present study also supported the last decade of bilingual research (e.g., Döpke, 2000; Hulk \& Müller, 2000; Müller \& Hulk, 2001) on the existence of contacts and potential interactions within the bilingual linguistic systems. The findings proved the trilinguals' dependence on translating and incorporating the pragmatic norms 
and cultural values of their first languages when they clashed with those of English. It conforms to Choi's (2019) report regarding the trilinguals' practices such as translation and code-switching. In the present study, the trilinguals' code-switching mostly occurred in Turkish and Persian communication rather than when using English. Then, the present study conflicts with earlier bilingual and multilingual studies (e.g., Chan, 2018, 2019; Klimpfinger, 2007) that considered code-switching to be an essential strategy in trilinguals' English communication. According to Chan $(2018,2019)$, using pure-Cantonese, pure-English, and pure-Putonghua in Hong Kong make communication difficult for trilinguals. The Iranian trilinguals communicated in pure Turkish and pure Persian without any difficulties, while their English communication required some trilinguals' practices such as translation and pragmatic or conceptual transfers.

The data obtained from the participants' speech acts illuminated the concept of identity synergism. In apology speech acts, the trilinguals did not perform all the strategies of apology listed by Fraser (1981). For instance, requesting hearer acceptance of an apology and acknowledging responsibility for an offending act were not observed in the data. The participants expressed regret for the offense and offered redress instead. Because of the cultural differences and the lack of sufficient pragmatic competence in the target language, the participants did not perform some strategies like announcing an apology, expressing obligation for an apology, requesting forgiveness for an offense, and promising forbearance from a similar offending act. Thus, this investigation is more in line with Bataineh and Bataineh (2008), who examined the Japanese language in Jordan in the apology speech act. This study asserts that in a Japanese apology, it is enough to say I am sorry, but in Jordan, an explanation for the offense is necessary.

This study also strengthened Cohen and Olshtain's (1981) research concerning Hebrew learners of English and the apology speech act. Their investigation revealed fewer traits of semantic formulae in the apology of nonnative speakers than native speakers. It also identified the occurrence of some transfers of Hebrew features in their apology strategies. The data from the trilinguals proved that these transfers did not occur in all apology strategies. In other words, the transfers from native languages, i.e., Persian, and Turkish to English, as the target language of the participants, occurred when acknowledging responsibility for the offending act and offering redress. In the other apology strategies, no transfers happened, and the participants employed the same formulaic structures in these three languages as the result of synergism among the language competences. Hence, the trilinguals principally preferred the apology in Persian, Turkish, and English, whereas for the native speakers of English, the expression of regret was most favored.

For the complaint strategies, the present study supported Bikmen and Marti's (2013) study on common complaint strategies, i.e., requests, hints, and annoyance. This study also revealed the urgency and emotion in the trilinguals' complaints when making the addressee stop the wrongdoing. The native speakers of English lacked this urgency and emotion. Thus, this investigation validated Tanck's (2004) findings regarding Korean non-native speakers' (NNSs) senses of urgency in questions and requests. The Korean NNSs added emotional requests and personal details to their complaints, which were irritating to Americans. The trilinguals were both direct and indirect in their complaint speech acts and their transfers were mostly positive from their native languages, i.e., Persian, and Turkish to the target language, i.e., English (Kasper, 1992).

Chen (1996) classified the refusal speech acts into an expression of regret, a direct refusal, and an excuse. The data analysis of the present investigation verified the results of Chen's (1996) investigation since the trilinguals tried these three strategies to create refusal speech acts. Han and Burgucu-Tazegül (2016) approved the frequent preferences of the participants for using indirect refusal strategies rather than direct ones. They found that Turkish EFL learners' pragmatic transfers coincided with their refusal strategies, and L1 pragmatic transfers decreased with an increase in EFL proficiency. Although the present study was able to validate the high frequency of indirect refusals, it also observed direct refusals, notably in Turkish communications. Since Persian and Turkish were the trilinguals' native languages, in this investigation, the pragmatic transfers occurred from both languages to English.

Although Mehrpour et al. (2016) surveyed pragmatic transfers in choice and content of semantic formulae, they disregarded non-verbal pragmatic transfers. They claimed there were differences in the sociocultural norms of English, Persian, and Kurdish in the refusal speech acts. The authors of the present study were highly skeptical of their findings as the trilinguals of this study demonstrated synergy in their pragmatic skills when constructing the refusal speech acts. These strategies were different from what the English native speakers of this study manifested. Mehrpour et al. (2016) ascertained the norm differences within English, Persian, and Kurdish 
languages. For them, the transfer of refusal speech acts mostly occurred from Kurdish as an L1 but not from the L2, i.e., Persian to the L3, i.e., English. For the present investigation, multidirectional transfers occurred in Persian and Turkish as the native languages (L1) and English as the target language. Consequently, the interactions between the Persian and Turkish language systems influenced the trilinguals' English communication. By analyzing the trilinguals' Persian, Turkish, and English communication, this study found pragmatic, semantic, and syntactic transfers among the mentioned linguistic systems.

In the request speech acts, the participants modified the requests and practiced internal modifiers or fillers more specifically, compared to external modifiers. Meanwhile, they tried pragmalinguistic formulae, e.g., Can you ...? Would you ...? I need ..., to express the requests without paying special attention to the modification devices. Cook and Liddicoat (2002) proved this issue in their study. In his study, Eslami-Rasekh (1993 discovered more direct strategies along with mitigators employed by Persian speakers). They do this to soften the illocutionary force. In other words, the non-native speakers create long speeches, in contrast to the native ones, to soften and intensify their communicative acts. The present study observed more indirect speech acts than direct ones in the trilinguals. Their speeches were also shorter than those of the native speakers of English. These results authenticated the study conducted by Jalilifar (2009), whose findings revealed the overuse of indirect strategies on the part of high-proficiency learners and the overuse of direct strategies by lowproficiency learners.

For offer, acceptance, and refusal speech acts, the cultural differences of the native languages, i.e., Persian and Turkish and the target language, i.e., English, made the trilinguals apply more native-like norms in English communication. This validated Davies and Harré (1990), who reported that identity was a context-bound issue. It also strengthened Brown et al. (2005), who determined that discourse or cultural membership shaped students' identities, and Al-Issa (2003) who investigated culture and its influence on an individual's interactions, interpretations, and apprehensions.

One significant result of the roles played by the trilinguals was the importance of non-verbal strategies in conveying meanings, which the previous studies overlooked. In the offer of repair, the trilinguals reported nonverbal strategies, such as gestures and mimes, more in Turkish and English communications than Persian, whereas, for the verbal strategies, the opposite was the case. The trilinguals transferred these non-verbal strategies from Turkish to English communication. Another issue regarding the video-recorded data was the volume of the trilinguals' voices in Turkish, but they communicated normally in Persian and English.

\section{Conclusion}

Nowadays, pragmatics and speech acts have attracted the attention of many researchers of applied linguistics. The present investigation has attempted to examine the gaps in this new human endeavor in the hope of finding synergy among the different linguistic systems of trilinguals. For this purpose, it has investigated the trilinguals who have acquired Persian and Turkish as their mother tongues and English as a foreign language in English language institutes.

The results revealed that in various speech acts, such as apology, refusal, complaint, and request, the native languages, i.e., Persian and Turkish, influenced the target language when compared with the English native speakers' norms. This impact is a positive interaction or multidirectional transfer among the trilinguals' native linguistic systems and their target language. As an example, for the acceptance of a request, the data revealed that not only did the first languages, i.e., Persian and Turkish influence the trilinguals' English communication, but the target language, i.e., English influenced their English communication as well.

This study concluded that the trilinguals may employ various identity resources to construct a mechanism using their trilingual knowledge called cognitive synergy, which allowed the languages to be used more effectively in combination than in isolation. Thus, by learning the English language, the trilinguals have created a new identity along with new pragmatic norms that synergistically work with the existing language systems, i.e., Persian and Turkish. In other words, to avoid any misunderstandings and interruptions in communication, the individuals make use of all the linguistic assets and conceptual strategies in a synergic way. 
The findings of this investigation may give researchers of multilingual issues new insights into what is happening in the mind of trilinguals. Teachers who face the challenges of multilingual realities may also find the results of the present study of interest. The findings can additionally provide educational decision-makers with a vision of trilingual contexts as a principal problematic issue in order to develop a common strategy for training trilingual teachers as well as the teachers of trilinguals through enhancing, renewing, and planning the educational programs.

\section{Conflict of interest}

The authors declare that they have no conflict of interest.

\section{Reference}

Al-Eryani, A. A. (2007). Refusal strategies by Yemeni EFL learners. The Asian EFL Journal, 9(2), 19-34. https:// www.asian-efl-journal.com/June_2007_EBook_editions.pdf

Al-Gahtani, S., \& Roever, C. (2011). Proficiency and sequential organization of L2 requests. Applied Linguistics, 3(1), 42-65. https://doi.org/10.1093/applin/amr031

Al-Issa, A. (2003). Sociocultural transfer in L2 speech behaviors: Evidence and motivating factors. International Journal of Intercultural Relations, 27(5), 581-601. https://doi.org/10.1016/S0147-1767(03)00055-5

Aliakbari, M., \& Amiri, M. (2018). Foreign language identity and Iranian learners' achievement: A relational approach. System, 76(3), 80-90. https://doi.org/10.1016/j.system.2018.05.009

Allami, H., \& Naeimi, A. (2010). A cross-linguistic study of refusals: An analysis of pragmatic competence development in Iranian EFL learners. Journal of Pragmatics, 43(1), 385-406. https://doi.org/10.1016/j. pragma.2010.07.010

Austin, J. L. (1962). How to do things with words. Clarendon Press.

Backus, A. M., \& Yagmur, K. (2017). Differences in pragmatic skills between bilingual Turkish immigrant children in the Netherlands and monolingual peers. The International Journal of Bilingualism, 2(1), 1-14. https://doi. org/10.1177/1367006917703455

Bataineh, F. R., \& Bataineh, F. R. (2008). A cross-cultural comparison of apologies by native speakers of American English and Jordanian Arabic. Journal of Pragmatics, 40(4),792-821. https://doi.org/10.1016/j. pragma.2008.01.003

Bayat, A. (2013). Life as politics how ordinary people change the Middle East (2nd ed.). Stanford University Press. https://doi.org/10.1111/j.1468-2427.2012.01192_6.x

Bikmen, A., \& Marti, L. (2013). A study of complaint speech acts in Turkish learners of English. Education and Science, 38(170), 253-265. https://doi.org/10.1145/3341042.3341059

Block, D. (2007). The rise of identity in SLA research, Post Firth and Wagner. The Modern Language Journal, 91(5), 863-876. https://doi.org/10.1111/j.1540 4781.2007.00674.x

Blum-Kulka, S., \& Olshtain, E. (1984). Requests and apologies: A cross-cultural study of speech act realization patterns (CCSARP). Applied Linguistics, 5(3), 196-213. https://doi.org/10.1093/applin/5.3.196

Brown, P., \& Levinson, S. C. (1987). Politeness: Some universals in language usage. Cambridge University Press. https://doi.org/10.1017/CBO9780511813085

Brown, B. A., Reveles, J. M., \& Kelly, G. J. (2005). Scientific literacy and discursive identity: A theoretical framework for understanding science learning. Science Education, 89(5), 779-802. https://doi.org/10.1002/ sce. 20069

Chamani, F., \& Zareipur, P. (2010) A cross cultural study of apologies in British English and Persian. Concentric: Studies in Linguistics, 36(1), 133-153.

Chan, K. L. R. (2019). Trilingual code-switching in Hong Kong. Applied Linguistic Research Journal, 3(4), 1-14. https://doi.org/10.14744/alrj.2019.22932

Chan, K. L. R. (2018). Being a 'purist' in trilingual Hong Kong: Code-switching among Cantonese, English, and Putonghua. Linguistic Research 35(1), 75-95. https://doi.org/10.17250/ khisli.35.1.201803.003

Chen, H.J. (1996). Cross-cultural comparison of English and Chinese metapragmatics in refusal. Indiana University. https://files.eric.ed.gov/fulltext/ED408860.pdf 
Choi, J. (2019). A child's trilingual language practices in Korean, Farsi, and English: From a sustainable translanguaging perspective. International Journal of Multilingualism, 16(4), 534-548. https://doi.org/10.1080 /14790718.2019.1593423

Cohen, A. D. (1996). Speech acts. In S. McKay \& N. Hornberger (Eds.), Sociolinguistics and language teaching (pp. 383-420). Cambridge University Press. https://doi.org/10.5785/13-2-189

Cohen, A., \& Olshtain, E. (1983). Apology: A speech act set. In N. Wolfson \& E. Judd (Eds.), Sociolinguistics and Language Acquisition (pp.18-35). Newbury House. https://doi.org/10.1017/S0047404500011672

Cohen, A. D., \& Olshtain, E. (1981). Developing a measure of sociocultural competence: A case study. Language Learning, 31(1), 113-134. https://doi.org/10.1111/j.1467-1770.1981.tb01375.x

Cohen, A. D., \& Shively, R. L. (2007). Acquisition of requests and apologies in Spanish and French: Impact of study abroad and strategy building intervention. Modern Language Journal, 91(2), 189-212. https://doi. org/10.1111/j.1540-4781.2007.00540.x

Cook, M., \& Liddicoat, A. J. (2002). The development of comprehension in interlanguage pragmatics: The case of request strategies in English. Australian Review of Applied Linguistics, 25(1), 19-39. https://doi.org/10.1075/ aral.25.1.02coo

Crystal, D. (1997). English as a Global Language. CUP. https://doi.org/10.1017/S0047404599301044

Davies, B., \& Harré, R. (1990). Positioning: The discursive production of selves. Journal for the Theory of Social Behaviour, 20(1), 43-63. http://dx.doi.org/10.1111/j.1468-5914.1990.tb00174.x

Döpke, S. (2000). Generation of and retraction from cross linguistically motivated structures in bilingual first language acquisition. Bilingualism: Language and Cognition, 3(3), 209-226. https://doi.org/10.1017/ S1366728900000341

Dörnyei, Z. (2007). Research methods in applied linguistics. Oxford University Press.

Duszak, A. (2002). Us and others: An introduction. In A. Duszak (Ed.), Us and Others. Social identities across languages, discourses and cultures (pp.1-28). Benjamins. https://doi.org/10.1075/pbns.98.01dus

Ellis, R. (2008). The study of second language acquisition (2nd ed.). Oxford University Press.

Elo, S., \& Kyngäs, H. (2008). The qualitative content analysis process. Journal of Advanced Nursing, 62(1), 107115. https:// doi: 10.1111/j.1365-2648.2007.04569. x.

Eslami-Rasekh, Z. (1993). A cross-cultural comparison of the requestive speech act realization patterns in Persian and American English. In L. Bouto \& Y. Kachru (Eds.), Pragmatics and language learning (pp. 85-103). Division of English as an International Language.

Fraser, B. (1981). On apologizing. In F. Coulmas (Ed.), Conversational routine: explorations in standardized communication situations and prepatterned speech (pp. 259-271). Mouton. https://doi.org/10.1017/ S0047404500000208

Goertzel, B. (2009). Cognitive synergy: A universal principle for feasible general intelligence. Proceedings of the 8th IEEE International Conference on Cognitive Informatics, ICCI 2009, June 15-17, 2009. Hong Kong, China. https://doi.org/10.1109/COGINF.2009.5250694

Gonzales, W. D. (2016). Exploring trilingual code-switching: The case of 'Hokaglish'. Paper presented at The 26th Annual Meeting of the Southeast Asian Linguistics Society, Manila, Philippines.

Han, T., \& Burgucu-Tazegül, A. (2016). Realization of Speech Acts of Refusals and Pragmatic Competence by Turkish EFL Learners. The Reading Matrix: An International Online Journal, 16(1), 161-178.

Heger, A. K., \& Gaertner, L. (2018). Testing the identity synergy principle: Identity fusion promotes self and group sacrifice, Self and Identity, 17(5), 487-499. https://doi.org/10.1080/15298868.2017.1422538

Hulk, A., \& Müller, N. (2000). Bilingual first language acquisition at the interface between syntax and pragmatics. Bilingualism: Language and Cognition, 3(3), 227-244. https://doi.org/10.1017/S1366728900000353

Hyrkstedt, I., \& Kalaja, P. (2003). Attitudes towards English and its functions in Finland: A discourse-analytic study. World Englishes, 17(3), 345-358. https://doi.org/10.1111/1467-971X.00108

Ishihara, N., \& Cohen, A. D. (2004). Strategies for learning speech acts in Japanese. Center for Advanced Research on Language Acquisition, University of Minnesota. http://www.carla.umn.edu/speechacts/Japanese / introtospeechacts/index.htm.

Jalilifar, A. (2009). Request strategies: Cross-sectional study of Iranian EFL learners and Australian native speakers. English Language Teaching, 2(1), 46-61. https://doi.org/10.5539/elt.v2n1p46

Jenkins, J. (2012). English as a Lingua Franca from the classroom to the classroom. ELT Journal, 66(4), 486-494. https://doi.org/10.1093/elt/ccs040

Jenkins, J., Cogo, A., \& Dewey, M. (2011). State-of-the-Art Article: Review of developments in research into English as a lingua franca. Language Teaching, 44(3), 281-315. https://doi.org/10.1017/S0261444811000115 
Kachru, B. B. (2003). Liberation Linguistics and the Quirk Concern. In B. Seidlhofer (Ed.), Controversies in Applied Linguistics (pp. 19-33). Oxford University Press. https://doi.org/10.1017/S026607840000523X

Kachru, Braj B. (1986). The alchemy of English. Pergamon.

Kasper, G. (1997). Can pragmatic competence be taught? http://www.lll.hawaii.edu/nflrc/NetWorks/NW6

Kasper, G. (1992). Pragmatic transfer. Second Language Research, 8(3), 203-231. https://doi. org/10.1177/026765839200800303

Kasper, G. (1996). Introduction: Interlanguage Pragmatics in SLA. Studies in Second Language Acquisition, 18(2), 145-148. doi:10.1017/S0272263100014856

Khatib, M., \& Ghamari, M. R. (2011). Mutual relations of identity and foreign language learning: An overview of linguistic and sociolinguistic approaches to identity. Theory and Practice in Language Studies, 1(12), 17011708. http://doi.org/10.4304/tpls.1.12.1701-1708

Klimpfinger, T. (2007). Mind you, sometimes you have to mix - The role of code-switching in English as a lingua franca. VIEWS - Vienna English Working Papers, 16(2). 36-61.

Kondo, S. (1997). The development of pragmatic competence by Japanese learners of English: Longitudinal study on interlanguage apologies. Sophia Linguistica, 41(1), 265284.

Kondo, S. (2008). Effects on pragmatic development through awareness-raising instruction: Refusals by Japanese EFL Learners. In E. Alcón \& A. Martínez-Flor (Eds.), Investigating pragmatics in foreign language learning, teaching and testing (pp. 153-177). Multilingual Matters. https://doi.org/10.21832/9781847690869-010

Kuo, I. C. (2006). Addressing the issue of teaching English as a lingua franca. ELT Journal, 60(3), 213-221. https:// doi.org/10.1093/elt/ccl001

Lightbown, P. M., \& Spada, N. (2006). How languages are learned (3rd ed.). Oxford University Press.

Lim, I., Hwang, J. (2019). Korean adult English learners' perceptions of the common grammatical features of English as a lingua franca. The Journal of Asia TEFL, 16(3), 876-893. http://dx.doi.org/10.18823/ asiatefl.2019.16.3.7.876

Liu, J. (2006). Measuring interlanguage pragmatic knowledge of EFL learners. Peter Lang.

Llurda, E. (2004). Non-native-speaker teachers and English as an international language. International Journal of Applied Linguistics, 14(3), 314- 323. https://doi.org/10.1111/j.1473-4192.2004.00068.x

Mehrpour, S., Ahmadi, M., \& Sabourian Zadeh, N. (2016). Cross-linguistic Comparison of speech acts of refusals: Evidence from trilingual EFL learners in English, Farsi, and Kurdish. Iranian Journal of Applied Language Studies, 8(2), 159-188. https://doi.org/10.22111/IJALS.2016.3084

Modiano, M. (2008). Colinguals among bilinguals. World Englishes, 27(1), 117-130. https://doi. org/10.1111/j.1467-971X.2008.00539.x

Monzoni, C. M. (2009). Direct complaints in (Italian) calls to the ambulance: The use of negatively framed questions. Journal of Pragmatics, 41(12), 2465-2478. https://doi.org/10.1016/j.pragma.2008.09.042

Müller, N., \& Hulk, A. (2001). Crosslinguistic influence in bilingual language acquisition: Italian and French as recipient languages. Bilingualism: Language and Cognition, 4(1), 1-21. https://doi.org/10.1017/ S1366728901000116

Ochs, E. (2008). Constructing social identity: A language socialization perspective. In S. F. Kiesling \& C. B. Paulston (Eds.), Intercultural Discourse and Communication (pp.78-91). Blackwell.

Palanac, A. (2019). Positive Psychology and mastery of the L2 academic self. Journal of Language and Education, 5(2), 86-94. doi: https://doi.org/ 10.17323/jle.2019.8569

Palovskaya, G., \& Lord, A. (2018). The Influence of Students' sociocultural background on the IELTS speaking test preparation process. Journal of Language and Education, 4(3), 69-76. https://doi.org/10.17323/2411-7390-2018-4-3-69-76

Paltridge, B. (2012). Discourse analysis: An introduction. Bloomsbury Publishing.

Riley, P. (2006). Self-expression and the negotiation of identity in a foreign language. International Journal of Applied Linguistics, 16(3) 295-318. https://doi.org/10.1111/j.1473-4192.2006.00120.x

Rose, K. R., \& Kasper, G. (2001). Pragmatics in language teaching. Cambridge University Press. https://doi. org/10.1017/CBO9781139524797

Schreier, M. (2012). Qualitative content analysis in practice. Sage.

Searle, J.R. (1975). Linguistics and the philosophy of language. In R. Bartsch, \& T. Vennemann (Eds.), Linguistics and neighboring disciplines (pp. 89-100). North-Holland.

Seidlhofer, B. (1999). Double standards: Teacher education in the Expanding Circle. World Englishes, 18(2), 233245. https://doi.org/10.1016/j.pragma.2014.10.006

Siebold, K., \& Busch, H. (2015). (No) need for clarity-Facework in Spanish and German refusals. Journal of Pragmatics, 75(1), 53-68. https://doi.org/10.1016/j.pragma.2014.10.006 
Sridhar, K (1986). Sociolinguistic theory and non-native varieties of English. Lingua, 68(1), 39-58. https://doi. org/10.1016/0024-3841(86)90022-7

Sung, C. (2008). Does accent matter? Investigating the relationship between accent and identity in English as a lingua franca communication. System, 60(5), 55-65. https://doi.org/10.1016/j.system.2016.06.002

Tajeddin, Z., Alemi, M., \& Razzaghi, S. (2015). Cross-cultural perceptions of impoliteness by native English speakers and EFL learners: The case of Apology speech act. Journal of Intercultural Communication Research, 43(4), 304-326. https://doi.org/10.1080/17475759.2014.967279

Takkaç Tulgar, A. (2016). The role of pragmatic competence in foreign language education. Turkish Online Journal of English Language Teaching, 1(1), 10-19. https://doi.org/10.32959/tojelt.229304

Tanck, S. (2004). Speech act sets of refusal and complaint: A comparison of native and non-native English speakers' production. TESOL Working Papers, 4(2), 1-22. https://doi.org/10.17606/M6XQ04

Thumboo, E. M. (2002). The three circles of English. Singapore University Press.

Ushioda, E. (2009). A person-in-context relational view of emergent motivation, self and identity. In Z. Dörnyei, \& E. Ushioda (Eds.), Motivation, language identity and the L2 self (pp. 215-228). Multilingual Matters. https:// doi.org/10.21832/9781847691293-012

Varghese, M., Morgan, B., Johnston, B., \& Johnson, K. A. (2005). Theorizing language teacher identity: Three perspectives and beyond. Journal of Language, Identity, and Education,4(1), 21-44. https://doi.org/10.1207/ s15327701jlie0401_2

Vásquez, C. (2011). Complaints online: The case of Trip Advisor. Journal of Pragmatics, 43(6), 1707-1717. https:// doi.org/10.1016/j.pragma.2010.11.007

Vygotsky, L. S. (1978). Mind in society: The development of higher psychological processes. Harvard University Press.

Walsh, C. M., \& Neff, L. A. (2018). We're better when we blend: The benefits of couple identity fusion. Self and Identity, 17 (5), 587-603. https://doi.org/10.1080/15298868.2018.1430062

Wang, L., Kirkpatrick, A. (2015). Trilingual education in Hong Kong primary schools: An overview. Multilingual Education, 5(3), 1-26. https://doi.org/10.1186/s13616-015-0023-8

Yamashita, J. (2008). Extensive reading and development of different aspects of L2 proficiency. System, 36(4), 661- 672. https://doi.org/10.1016/j.system.2008.04.003 